Article

\title{
Participatory Approach to Gap Analysis between Policy and Practice Regarding Air Pollution in Ger Areas of Ulaanbaatar, Mongolia
}

\author{
Bonjun Koo ${ }^{1, *(\mathbb{D})}$, Jong-Il Na ${ }^{2}$, Throstur Thorsteinsson ${ }^{3}\left[\right.$ and Ana Maria Cruz ${ }^{1, *}$ \\ 1 Disaster Prevention Research Institute, Kyoto University, Uji 611-0011, Kyoto, Japan \\ 2 Korea Disaster Relief Association, Seoul 04088, Korea; rajongil@relief.or.kr \\ 3 Environment and Natural Resources, University of Iceland, 102 Reykjavik, Iceland; thorstur@hi.is \\ * Correspondence: koo.bonjun.77e@st.kyoto-u.ac.jp (B.K.); cruznaranjo.anamaria.2u@kyoto-u.ac.jp (A.M.C.); \\ Tel.: +81-774-38-4038 (B.K.); +81-774-38-4035 (A.M.C.)
}

Received: 10 February 2020; Accepted: 16 April 2020; Published: 18 April 2020

\begin{abstract}
Ulaanbaatar, the capital of Mongolia, suffers from severe air pollution during the long winter months, and its air pollution levels are among the highest in the world. Residents in the ger areas of Ulaanbaatar are unable to take advantage of the laws and policy regulations to reduce air pollution despite years of efforts to address this issue by international and local organizations including the government of Mongolia (GoM). Important challenges and barriers that have limited the success of various governmental policies that tackle air pollution problems were identified through participatory approaches. In order to do this, personal interviews were conducted with various stakeholders such as officials from central and local governments, government agencies, non-governmental organizations (NGOs), international organizations, and academia. Moreover, a workshop was conducted to elucidate the views of ger area community members in Ulaanbaatar. Based on the results of these interviews and workshop, the gaps between the policy approaches of the government, the actual conditions, and the desired situations of the residents to improve air quality in Ulaanbaatar were analyzed. The large gaps that were identified between the national and local perspectives on air pollution issues demonstrated that the reduction of air pollution in Ulaanbaatar requires solving fundamental and complex problems based on a better understanding of the specific conditions and needs of the residents of the ger areas. Moreover, active participation and discussion of the residents at the workshop indicated that community-based approaches could be applied in the cultural context of Mongolia with promising results in finding solutions.
\end{abstract}

Keywords: participatory approach; participatory workshop; air pollution; sustainable local decision-making

\section{Introduction}

Air pollution is a significant cause of disease and death rates, and the greatest health impacts from air pollution worldwide occur among the poorest and most vulnerable populations [1]. According to the 2016 WHO global urban ambient air pollution database, $98 \%$ of cities in low- and middle-income countries with a population of over 100,000 do not meet WHO air quality guidelines [2]. Developing countries suffer the greatest impact from air pollution in terms of life, economic loss, and environmental degradation. Air pollution is recognized as a pressing sustainability concern and it is directly mentioned in two sustainable development goals (SDG) targets: SDG 3.9 (substantial reduction of health impacts from hazardous substances) and SDG 11.6 (reduction of adverse impacts of cities on people) [3].

Around 3 billion people-more than $40 \%$ of the world's population-largely in developing countries, still rely on biomass fuels for their domestic energy needs [4]. Biomass and coal smoke contain many 
pollutants that are hazardous to human health such as particulate matter, carbon monoxide, nitrogen dioxide, sulfur oxides (mainly from coal), formaldehyde, and polycyclic organic matter (including carcinogens such as benzo (a) pyrene) [5]. Indoor air pollution, in particular, from the combustion of solid fuels is the cause of many diseases in developing countries such as acute respiratory infections and otitis media (middle ear infection), chronic obstructive pulmonary disease, lung cancer (from coal smoke), asthma, cancer of the nasopharynx and larynx, tuberculosis, perinatal conditions and low birth weight, and eye diseases such as cataract and blindness [6]. Indoor air pollution is a major global public health threat requiring increased efforts in the areas of research and policymaking [5]. Therefore, a more systematic approach for the development and evaluation of interventions with a clearer recognition of the interrelationships between poverty and dependence on polluting fuels is desirable [7].

Ulaanbaatar, in Mongolia, suffers from severe air pollution. During the long cold season from November to March, air pollution levels in Ulaanbaatar are among the highest in the world [8]. In the winter of 2017 (Figure 1), the mean concentration of particulate matters was 5-10 times higher than that of the World Health Organization guideline.

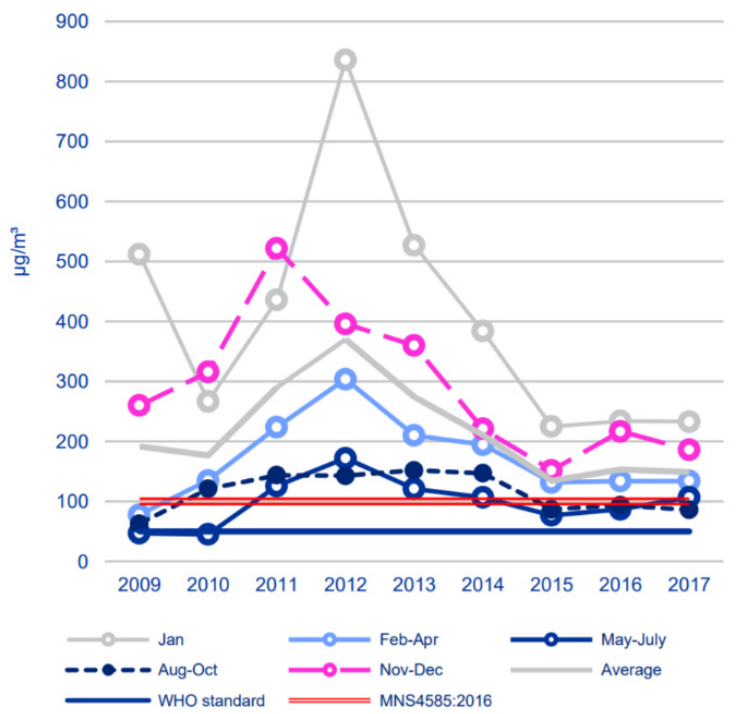

(a)

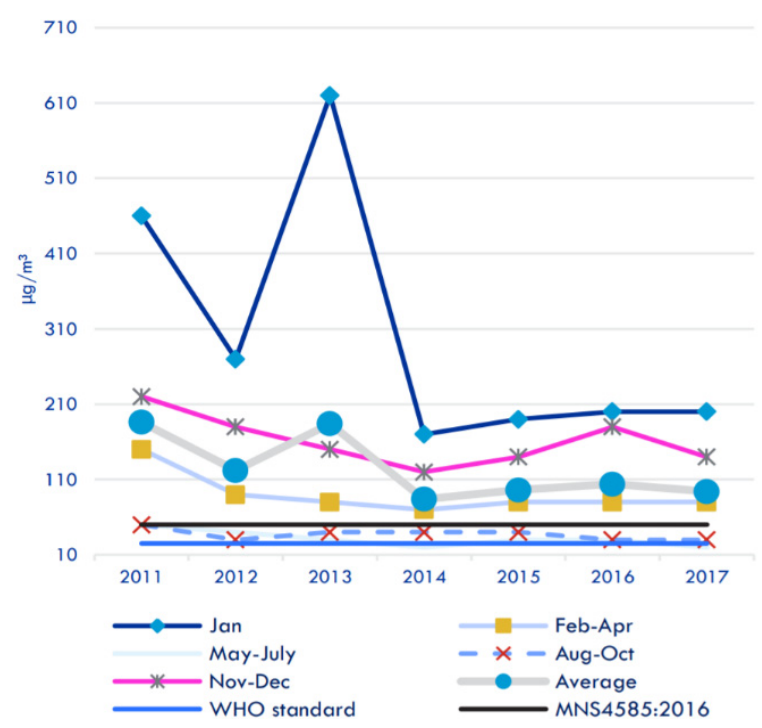

(b)

Figure 1. Average concentration of (a) $\mathrm{PM}_{10}$ in air for the period 2009-2017 and (b) $\mathrm{PM}_{2.5}$ for the period 2011-2017 in Ulaanbaatar for different seasons [9].

During the winter season, especially in the ger areas of Ulaanbaatar, when temperatures are $-20^{\circ} \mathrm{C}$ or less, the use of coal and wood fuels for heating increases rapidly and the air pollution is aggravated [10]. Households in the ger areas, named so for the traditional felt tents many live in, account for a considerable proportion of air pollutant emissions of the whole city owing to coal usage for heating [11]. Since most of the gers are not connected to the central heating system, they use a coal-burning stove (Figure 2).

The ger area is a geographical area on the outskirts of Ulaanbaatar, where a significant percentage of the citizens reside in traditional gers and individual detached houses that are either built with adobe or bricks [12]. After the collapse of the Soviet Union, lack of housing supply owing to rapid urbanization has resulted in an expansion of informal settlements known as the ger areas [13]. The Law of Mongolia on Land and the Law on Allocation of Land to Mongolian Citizens for Ownership allow citizens to privatize land for residential purposes [14,15]. These policies enable the residents to obtain legal ownership of their occupied land in the ger areas [13]. Combined heat and power (CHP) plants through district heating $(\mathrm{DH})$ networks provide heat and hot water to Ulaanbaatar's urban centers and smaller cities [16]. Most of the urban buildings have access to DH. However, most of the ger households are not connected to the DH networks, and hence, they rely on smaller boilers and traditional heating stoves that burn coal and wood inefficiently [16]. Ulaanbaatar receives electricity from the central 
energy system (CES) grid, which mainly consists of five coal-fired power plants [17]. In the ger areas, around $95 \%$ of the homes are presently connected to the grid, which is unable to deal with the load [17].

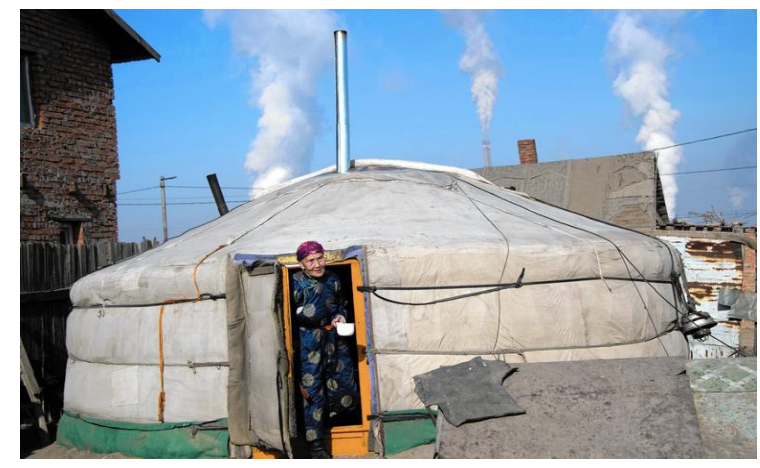

(a)

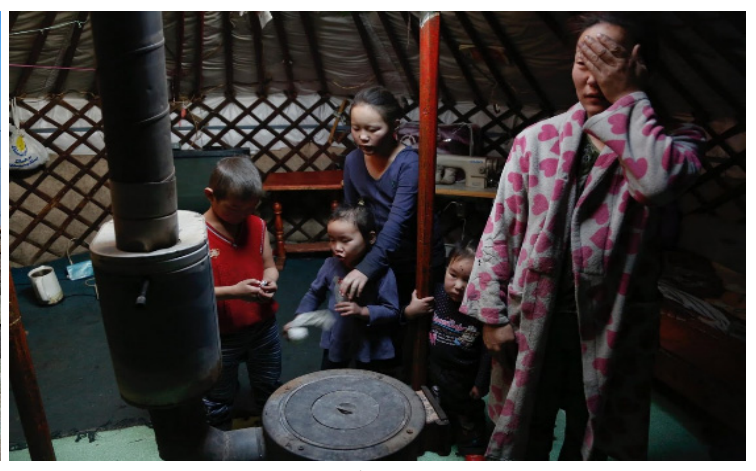

(b)

Figure 2. (a) Ger, the traditional Mongolian dwelling, is a felt tent (Source: Johannes Eisele /AFP/Getty Images); (b) it is commonly heated using a coal-burning stove (Source: B. Rentsendorj/Reuters, 2017).

In Mongolia, more than $70 \%$ of the population lives in urban areas, and as of 2015, approximately 1.37 million people live in Ulaanbaatar [18]. Recent statistics estimate that there are 800,000 residents in the ger areas comprising $60 \%$ of Ulaanbaatar's total population [19]. Owing to the fast urbanization rate in Ulaanbaatar, the poor live in gers in the city and use wood, coal, and even garbage as fuel for their cooking and heating. In the city, a large amount of combustion exhaust and particulate matter from the coal-fired thermal power plants also contribute to the severe air pollution (Figure 3a). This results in Ulaanbaatar being covered with smog throughout the winter (Figure 3b). Especially at night, when the temperature falls to $-30{ }^{\circ} \mathrm{C}$ and temperature inversion occurs during the long and cold winter season from mid-October to April, pollutants stagnate in the city for a long time and the air pollution levels are more than 10 times the national environmental standards. Thus, in winter, the citizens suffer from respiratory diseases such as pneumonia, bronchitis, asthma, and emphysema.

Existing studies on air pollution in Ulaanbaatar focus on analyses of trends of air pollution levels, sources [20-23], and the health problems of citizens caused by air pollution [24-27]. The government of Mongolia (GoM) in collaboration with national and international organizations deals with air pollution and consequent problems in a number of ways including adoption of law and policy regulations on prohibition of coal usage in certain areas [12]. Despite such efforts, air pollution issues in Ulaanbaatar persist. It is argued that the measures have not taken into consideration the needs and living conditions of residents in the ger areas, which are important in solving the air pollution crisis. Therefore, this study reviews the existing laws and policies related to air pollution in Mongolia and analyzes them by taking into account the perspectives of stakeholders and residents through participatory approaches to suggest policy directions that can minimize these gaps.

The importance of participation in fostering social sustainability of communities and places is that it allows for communities to express their needs and aspirations, which subsequently impacts the policy-making processes [28]. Furthermore, the setting up of environmental policies based on the concerns of members of a society corresponds to the implementation of a real vision of social transformation, and that of sustainable development in all its dimensions: Economic, social, and ecological [29]. Air pollution is one of the most urgent issues for policymaking and requires mutual cooperation among various stakeholders. Voluntary and active participation of the public is essential for the implementation of policies aimed at reducing air pollution as these require behavioral changes. 


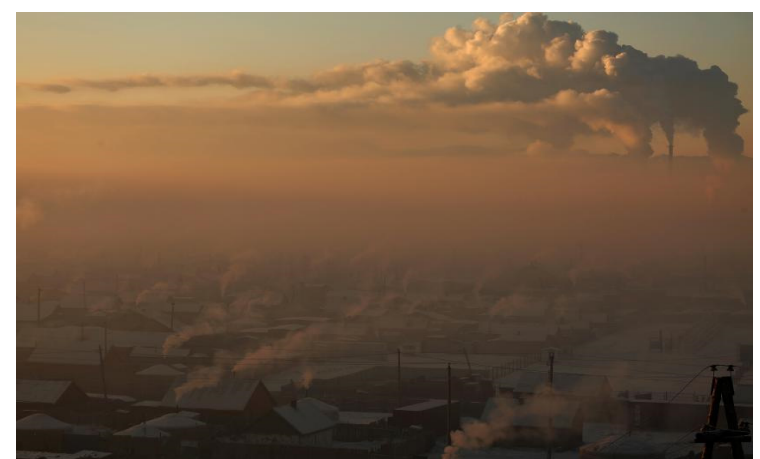

(a)

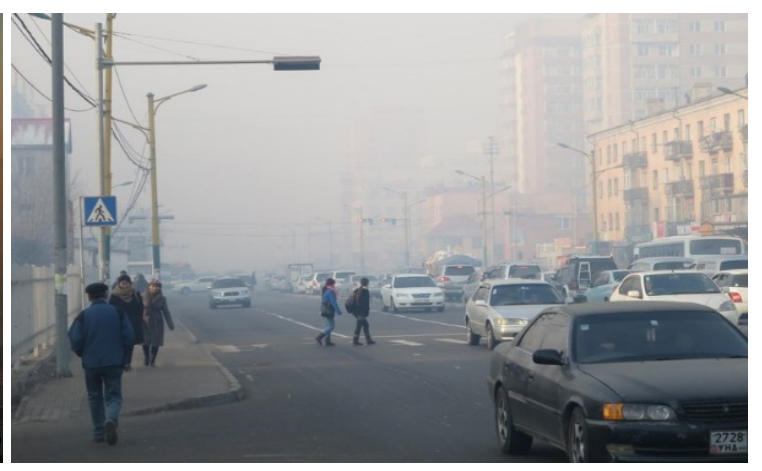

(b)

Figure 3. (a) Power plant chimneys stand behind a coal-burning neighborhood covered in a thick haze on the outskirts of Ulaanbaatar (Source: B. Rentsendorj/Reuters, 2017); (b) commuters battle the late-afternoon smog in downtown Ulaanbaatar (Source: Peter Bittner, 2016).

In recent years, there has been a steady flow of literature arguing for a participatory type of policy analysis that emphasizes the need for social interaction in order to be able to change current policies [30]. Practical tools of participatory policy analysis are currently being implemented such as gaming/simulations, consensus conferences, scenario workshops, and computer-based group decision support systems [30].

\section{Methods}

Data for this study were obtained through a review of the literature, from government policy and law, and face-to-face interviews. Interviews were conducted with various stakeholders including officials of central and local government agencies, non-governmental organizations (NGOs), international organizations, and academia to identify the current situation of air pollution in Ulaanbaatar and their risk perception as well as the response strategies.

Furthermore, a workshop was conducted with members of a ger area community in Ulaanbaatar. The purpose of the workshop was to collect opinions from the residents and to develop a participatory and community-based action plan to address the indoor air pollution problems that they are faced with.

\subsection{Interviews with Stakeholders and Data Collection}

A series of interviews with central and local government officials, experts from academia, NGOs, and international organizations who work on air pollution issues in Ulaanbaatar was conducted. An officer in charge of environmental assessment and audit in the Ministry of Environment and Tourism was first contacted and interviewed. From this, official contact information of relevant officials and experts from the Ministry of Energy, the National Agency for Meteorology and Environmental Monitoring, the Ulaanbaatar City Government, and the National University of Mongolia were obtained. These contact persons were approached directly by phone, e-mail, or arranged meetings to seek interviews. The interviews were conducted for about 30 minutes to an hour by visiting each organization, and the interviewees were either one or two persons, from each organization. For each interviewee, an in-depth interview was conducted with open and follow-up questions on the current practices and interests. Interviewees were encouraged to present their views on Ulaanbaatar's air pollution freely without posing specific questions. Interviews were written without recording because the interviewees were concerned that their personal views would be viewed as representing that of their organization. Through the interviews and additional meetings, eight interviewees shared their expertise and experiences regarding air pollution and air quality management and provided relevant data including polices, regulations, and reports.

Local and international perspectives on the air pollution issue in Ulaanbaatar were also gathered through the interviews and meetings with NGOs and international organizations that were involved in 
air pollution and other issues pertaining to the ger areas. They explained their activities on completed and ongoing projects concerning air pollution in Ulaanbaatar and shared relevant brochures and reports. Interviews were also conducted with local government officials on installed air pollution warning and response systems and their effectiveness at the ger area/citizen level.

\subsection{Community-based Participatory Workshop}

A community-based participatory workshop was conducted with the residents of a ger area in Ulaanbaatar to identify current issues, learn about their perspectives regarding air pollution risk management, and develop a collaborative action plan.

Some of the Mongolian NGOs that work with local communities of the ger areas in Ulaanbaatar were contacted by e-mail, and several of those were visited for consultation meetings. Through the meetings, an NGO named People Centered Conservation (PCC) that has conducted community-based conservation practice and research in the ger areas for more than a decade by working closely with the residents was selected to assist in the workshop. Three preparatory meetings were held with PCC to discuss and prepare for the workshop. In the meetings, the purpose of the research and explanation of the concepts and plans of the workshop method applied to the research were provided. PCC had arranged a meeting with the governor of the 7th sub-district of the Songino Khairkhan District, in which the governor promised support to recruit residents and provide a conference room for the workshop.

The workshop was conducted on 9 March 2017, in the conference room of the 7th sub-district of the Songino Khairkhan District. Songino Khairkhan District is evaluated as the most polluted area in Ulaanbaatar according to the air quality monitoring system. The first author of this paper facilitated the workshop in Mongolian, and a staff member from PCC translated between Mongolian and English for him and the participants when communication difficulties occurred. Refreshments were provided to the participants to encourage them to speak in an informal atmosphere. Twenty residents of the district voluntarily attended the workshop and participated in the discussion for three hours. Utilizing the Yonmenkaigi system method (YSM), participants identified current issues and perspectives concerning air-quality risk management in Ulaanbaatar and expressed their needs and desired situations. The YSM is a participatory method to support group decision making, which fosters small and modest breakthroughs and/or innovative strategy development [31]. The YSM has found wider acceptance in terms of both the number of study areas and subjects of application. For example, the method has been applied to both rural and urban areas in Japan as well as in Korea, China, and Indonesia [31].

\section{Results}

\subsection{Results of Interviews with Stakeholders}

Stakeholders involved with air pollution issues in Ulaanbaatar agree that the air pollution issue is ongoing for decades and it has not improved. In winter, the sky in Ulaanbaatar is covered in smog and smells of smoke emanating from the burning coal (Figure 3).

A government official from the Ministry of Environment and Tourism said that the GoM regards the air pollution issue in Ulaanbaatar as a key priority and it is making a number of efforts to address this problem. The officer added that the winter of 2017 (study year) was extremely cold when compared with the previous year leading to a high quantity of energy use for heating in each household, which made the air pollution worse. He added that in addition to the increased coal use by residents in the ger areas, they were using inappropriate materials such as rubber, plastic, and garbage as fuels for their heating. According to the officer, the government has prepared countermeasures including policies and regulations, however these were not effective because of the low levels of consciousness of the citizens. In addition, the GoM, in partnership with national and international organizations has implemented projects to reduce air pollution and improve the air quality in Ulaanbaatar.

According to the head of the Air Quality Monitoring Division of the Air Pollution Reducing Department, an implementing agency of the Governor of Capital City, almost $80 \%$ of the air pollution 
in Ulaanbaatar is caused by coal burning in the ger areas. In spite of the fact that the amount of coal burned in thermal power plants are the largest, their contribution to air pollution in Ulaanbaatar is not high as they have tall chimneys with pollution abatement facilities. There are 14 ambient air quality monitoring stations in Ulaanbaatar, of which 10 belong to the National Agency for Meteorology and Environment Monitoring of Mongolia (NAMEM), which is under the Ministry of Environment and Tourism, and 4 belong to the Air Quality Department of the Capital City. In addition, a fixed-point automatic monitoring system was installed through a project by the Japan International Cooperation Agency (JICA) to strengthen the air pollution control capability.

An officer-in-charge for air quality information and assessment in the Department of Environmental Monitoring of NAMEM explained that an 'Intelligent Air Quality Management System' was developed to provide accurate information on air pollution in Ulaanbaatar and it is available online and for smartphones. The website provides up-to-date information on real-time air quality in Ulaanbaatar, sectoral activities including projects, laws and regulations, statistical data, and suggestions for reducing air pollution.

A professor from the National University of Mongolia presented a past project on a smoke filtering device that is applied in thermal power plants and showed a sample of that in the laboratory. The professor mentioned that the device would be transformed for home use and distributed to households in the ger areas in Ulaanbaatar.

\subsection{Results of Community-Based Participatory Workshop}

The workshop focused on understanding residents' perception of air pollution issues and their specific needs and challenges (or barriers) in adopting air pollution reduction policies proposed by the government. The workshop utilized YSM, which is composed of four main steps: Conducting a SWOT analysis, completing the Yonmenkaigi chart, debating, and presenting the group's action plan [31]. As a facilitator of the workshop, the first author of this paper explained the purpose of the workshop to the participants and introduced the workshop's agenda, schedule, and method (Table 1).

Table 1. Program agenda for the workshop.

\begin{tabular}{cccc}
\hline No. & Process & Duration & Contents \\
\hline 1 & Guidance & $10 \mathrm{~min}$ & Introduce purpose and process of the workshop \\
\hline 2 & SWOT analysis & $40 \mathrm{~min}$ & Brainstorm and identify the current status of the ger area \\
\cline { 3 - 4 } & $\begin{array}{c}\text { Group } \\
\text { discussion }\end{array}$ & $10 \mathrm{~min}$ & Determine a topic for the group discussion \\
\cline { 3 - 4 } & Presentation & $20 \mathrm{~min}$ & $\begin{array}{c}\text { Present the action plans by each group and develop the } \\
\text { collaborative action plans by all the groups }\end{array}$ \\
\hline 5 & Wrap-up & $20 \mathrm{~min}$ & $\begin{array}{c}\text { Share impressions and comments from the participants } \\
\text { regarding the workshop }\end{array}$ \\
\hline
\end{tabular}

In the SWOT analysis session, participants hesitated to speak first; however, a male participant raised his hand and began to share various ideas about air pollution and the issues pertaining to the ger area. Then, the other participants agreed with most of his ideas, and they began to express their opinions carefully. The workshop ran smoothly, as the active exchange of opinions increased, and discussions started. The topic for the group discussion was 'how to reduce air pollution in the ger areas.'

The participants were divided into groups of their choice based on four functions: Management, Information, Human Resources, and Physical Resources. Each group wrote action plans to reduce air pollution in the ger areas on Post-it notes from the point of view of their function. Moreover, they developed the ideas and posted them to the chart (Figure 4). Then, each of the four groups presented their ideas to all the participants, and based on that, combined collaborative action plans were developed on the chart. 
The workshop participants were aware that their area is the most polluted area in Ulaanbaatar according to the air quality monitoring system and hence, they had a keen interest in resolving the air pollution issue. They noted that the air pollution countermeasures proposed by the GoM have not comprehensively considered their needs and real living conditions, hence leading to the continuation of the vicious cycle of air pollution in Ulaanbaatar.

The YSM chart developed by the participants was organized as shown in Table 2. The results show that the participants were relatively familiar with ways to reduce air pollution in Ulaanbaatar. Participants expressed opinions stating that the use of clean and renewable energies such as wind power, electricity, and solar heat and the introduction of green technologies should be encouraged. They said that if information on the use of gaseous fuels such as LPG for cooking is provided or facilities for its utilization are built, the use of low-grade coals will be reduced. Interesting comments suggested that providing information on insulation materials and improving the performance of the insulation materials would increase the insulation effect of ger areas and reduce the use of coal. It can be seen that they were aware that the use of coal in their homes for heating and cooking contributed significantly to air pollution in Ulaanbaatar.

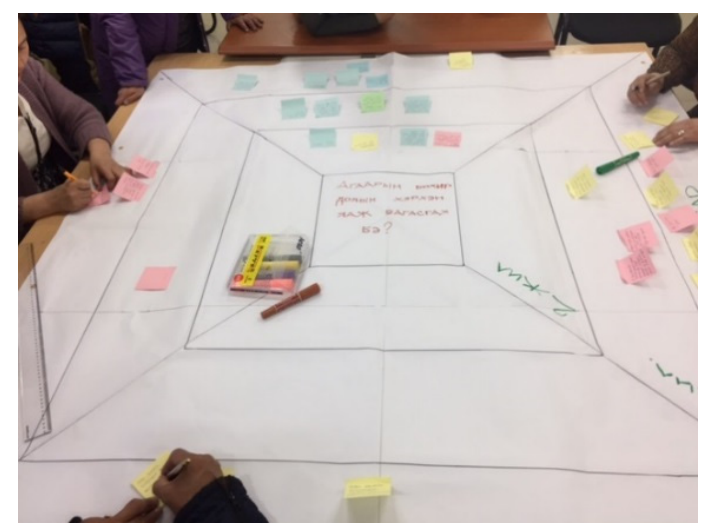

(a)

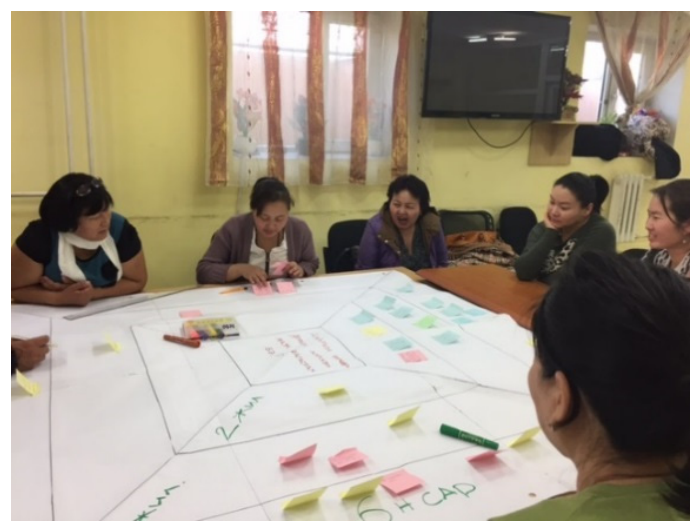

(b)

Figure 4. (a,b) Workshop participants developing the Yonmenkaigi system method (YSM) chart.

In terms of management, the group suggested the need for strict regulations such as population control, closure of wool washing factories, and restrictions on used car imports. In addition, they said that they would like to have educational programs, discussions about the environment, and corporate social contribution to promote public awareness on the environment. They seemed to be concerned about the health problems caused by air pollution, given that the information group, the physical resources group, and the other participants had a keen interest in the effectiveness of oxygen cocktails and discussed it at some length. Residents revealed that they were buying 1 US dollar cans of pressurized oxygen from supermarkets to squirt into their juices, waters, and other drinks to defend themselves from the crippling smog [32,33]. Advertisements in Ulaanbaatar claim that 'drinking just one oxygen cocktail is equal to a three-hour-walk in a lush forest' [34].

Among the first 20 participants, 14 participants stayed until the end of the workshop, 2 of whom were males and the rest were females. Of those who stayed, in terms of the age of the participants, nine were in their $50 \mathrm{~s}$, one in the $30 \mathrm{~s}$, three in their $40 \mathrm{~s}$, and one in the $60 \mathrm{~s}$. The workshop was held on a weekday afternoon, and at that time, most men were engaged with work. 
Table 2. Collaborative action plans from the workshop.

\begin{tabular}{|c|c|c|c|}
\hline Roles & Within 6 Months & Within 1 Year & Within 2 Years \\
\hline Management & $\begin{array}{ll}\text { - } & \text { Wind generators } \\
\text { - } & \text { Waste generation } \\
\text { - } & \text { Population control } \\
\text { - } & \text { Electricity and } \\
& \text { solar heating }\end{array}$ & $\begin{array}{l}\text { - } \quad \text { The 5th power plant } \\
\text { - Closure of wool } \\
\text { - } \quad \text { Reshing factories } \\
\text { car import } \\
\text { - } \quad \text { Integrated heating system }\end{array}$ & $\begin{array}{ll}\text { - } & \text { Coking coal } \\
\text { - } & \text { Water-pipe system } \\
\text { - } & \text { Moving to } \\
\text { - } & \text { an apartment } \\
\text { Population control }\end{array}$ \\
\hline Information & $\begin{array}{l}\text { - Information on LPG } \\
\text { for cooking } \\
\text { - } \quad \text { Educational programs for } \\
\text { the disabled and children } \\
\text { - Studies on } \\
\text { insulation materials }\end{array}$ & $\begin{array}{ll}\text { - } & \text { Various brain } \\
\text { - } & \text { storming sessions } \\
\text { Information on } \\
\text { oxygen cocktail }\end{array}$ & $\begin{array}{l}\text { - Information and } \\
\text { educational programs } \\
\text { on waste management } \\
\text { - } \quad \begin{array}{l}\text { Environmental social } \\
\text { contribution activities } \\
\text { of corporates }\end{array}\end{array}$ \\
\hline $\begin{array}{l}\text { Human } \\
\text { Resources }\end{array}$ & $\begin{array}{l}\text { - Investigation of cars } \\
\text { - } \quad \text { Survey on the outskirts of } \\
\text { the city } \\
\text { - Promoting awareness } \\
\text { through artists, mass } \\
\text { media, and students }\end{array}$ & $\begin{array}{l}\text { Public hearings between } \\
\text { government and citizens } \\
\text { for the 5th power } \\
\text { plant establishment } \\
\text { - Heat sharing }\end{array}$ & $\begin{array}{l}\text { Provide incentives for } \\
\text { people to develop } \\
\text { clean technologies }\end{array}$ \\
\hline $\begin{array}{l}\text { Physical } \\
\text { Resources }\end{array}$ & $\begin{array}{ll}\text { - } & \text { Development and } \\
\text { improvement of various } \\
\text { insulation materials } \\
\text { - } & \text { Improved coal } \\
\text { - } & \text { Gas usage for cooking }\end{array}$ & $\begin{array}{ll}\text { - } & \text { Oxygen cocktail } \\
\text { - } & \text { Improvement of } \\
\text { reconstruction and } \\
\text { urban planning } \\
\text { - } & \text { More monitoring systems } \\
\text { - } & \text { Water heating system } \\
\text { - } & \text { Subsidy for electric charges }\end{array}$ & - Use of solar panel \\
\hline
\end{tabular}

\subsection{Gap Analysis between Policy and Practice}

In order to compare air pollution policies of Mongolia and the actual conditions of the ger areas in Ulaanbaatar, the Law on Air Pollution Reduction in the Capital City adopted by the Parliament in 2011 was reviewed [35]. The statute consists of 4 chapters and 14 articles. The core of the decree is well documented in Article 4, which consists of the basic principles for ensuring a phased action plan and implementation for the reduction of air pollution in Ulaanbaatar. Article 4 Protocol 1 provides seven practical steps to reduce air pollution in Ulaanbaatar.

Despite these laws and policies, the air pollution in Ulaanbaatar has not reduced, but worsened over the recent years. Based on the results of the interviews and workshop conducted in this study, the reasons for this situation are analyzed and shown in Table 3. 
Table 3. Gap analysis between policy and practice.

\begin{tabular}{|c|c|c|}
\hline Policy Approaches (2011) & $\begin{array}{l}\text { Actual Conditions (2017) } \\
\text { Results of Interviews }\end{array}$ & $\begin{array}{l}\text { Desired Situations (2017) } \\
\text { Results of Workshop }\end{array}$ \\
\hline $\begin{array}{l}\text { Expand the energy sources and the network of } \\
\text { transmission and distribution and increase the } \\
\text { capacity. }\end{array}$ & $\begin{array}{l}\text { Residents in the ger areas still have a high dependence } \\
\text { on coal and wood fuels for their domestic energy. } \\
\text { Moreover, the winter of } 2017 \text { was extremely cold when } \\
\text { compared with the previous year, and hence, the energy } \\
\text { use for heating in each household had soared making } \\
\text { air pollution worse. }\end{array}$ & $\begin{array}{l}\text { The workshop participants were also looking to expand } \\
\text { their energy sources, especially clean/renewable energy } \\
\text { such as wind power, electricity, and solar heat. } \\
\text { Furthermore, they were expecting the GoM to } \\
\text { encourage the use of green technologies to increase } \\
\text { energy capacity and efficiency. }\end{array}$ \\
\hline $\begin{array}{l}\text { Designate areas with severe pollution as air } \\
\text { pollution improvement areas and distribute } \\
\text { stoves that effect complete combustion and use } \\
\text { refined fuels that emit less pollutants. }\end{array}$ & $\begin{array}{l}\text { No special measures were taken to designate the special } \\
\text { areas of concern by the GoM. Meanwhile, improved } \\
\text { stoves were distributed to several people in the ger } \\
\text { areas, but the residents sold them to people in other } \\
\text { provinces and used the money for their living expenses. }\end{array}$ & $\begin{array}{l}\text { The workshop participants argued that as air pollutants } \\
\text { from the east of Ulaanbaatar are added to their area (the } \\
\text { west of Ulaanbaatar) owing to prevailing winds from } \\
\text { the east, their area has the highest pollution levels every } \\
\text { winter as per the air quality monitoring system. They } \\
\text { added that specific and targeted efforts for this highly } \\
\text { polluted area are needed and that these efforts have to } \\
\text { be in agreement with the requirements of the local ger } \\
\text { area residents to be effective. }\end{array}$ \\
\hline $\begin{array}{l}\text { - Create an incentive system for reducing the } \\
\text { electricity fee to the households. }\end{array}$ & $\begin{array}{l}\text { The GoM has approved a regulation to cut the } \\
\text { electricity tariff at night (from } 9 \text { p.m. to } 6 \text { a.m.) for the } \\
\text { ger area households to zero. This measure is not } \\
\text { realistic because residents in the ger area do not have an } \\
\text { electric stove as they are not affordable. }\end{array}$ & $\begin{array}{l}\text { The workshop participants need more proactive } \\
\text { measures, including, for example, a subsidy system for } \\
\text { other energy options that considers their living } \\
\text { conditions. }\end{array}$ \\
\hline $\begin{array}{l}\text { - Support citizens and companies to introduce } \\
\text { advanced technologies and present new } \\
\text { initiatives to reduce the air pollution in } \\
\text { Ulaanbaatar. }\end{array}$ & $\begin{array}{l}\text { The National University of Mongolia has developed a } \\
\text { smoke filtering device that is utilized in the thermal } \\
\text { power plants. This device would be transformed for } \\
\text { home use and distributed to households in the ger areas } \\
\text { in Ulaanbaatar. However, the government's financial } \\
\text { support for academic research and technology } \\
\text { development are still insufficient. }\end{array}$ & $\begin{array}{l}\text { The workshop participants expected social contribution } \\
\text { activities by corporates to promote public awareness } \\
\text { about the environment. They had the idea that fines } \\
\text { must be imposed on polluting companies even if they } \\
\text { would be damaging to their immediate interests. } \\
\text { Moreover, they expressed that the power plants and } \\
\text { factories should switch to cleaner processes even if } \\
\text { consumer bills and prices go up. }\end{array}$ \\
\hline
\end{tabular}


Table 3. Cont.

\begin{tabular}{|c|c|c|}
\hline Policy Approaches (2011) & $\begin{array}{l}\text { Actual Conditions (2017) } \\
\text { Results of Interviews }\end{array}$ & $\begin{array}{c}\text { Desired Situations (2017) } \\
\text { Results of Workshop }\end{array}$ \\
\hline $\begin{array}{l}\text { Provide long-term low-interest loans to the } \\
\text { households in the ger areas through land } \\
\text { collateral and allow them to build houses. } \\
\text { Promote population migration to the provinces } \\
\text { through local investment and job creation. } \\
\text { - Promote development policies for the outskirts } \\
\text { of the capital and control localized population } \\
\text { concentration. } \\
\text { Redevelop and construct apartments for the ger } \\
\text { areas and prioritize infrastructure construction } \\
\text { such as houses and roads. }\end{array}$ & $\begin{array}{l}\text { Residents in the ger area are living below the average } \\
\text { monthly wage in Mongolia cannot afford to build a new } \\
\text { house or move to an apartment. Besides, owing to } \\
\text { capital-centered development, social infrastructure is } \\
\text { concentrated in Ulaanbaatar, making it difficult to } \\
\text { redistribute the population. The infrastructure of the } \\
\text { ger areas is still underdeveloped and the city is } \\
\text { undergoing redevelopment and construction of new } \\
\text { towns including construction of apartments. }\end{array}$ & $\begin{array}{l}\text { The workshop participants expected that infrastructure } \\
\text { in the ger areas would expand in the short term and } \\
\text { they will be able to move to an apartment in the long } \\
\text { term. They also expected improvements to } \\
\text { reconstruction and urban planning. }\end{array}$ \\
\hline $\begin{array}{l}\text { Minimize the use of raw coal and other } \\
\text { substances that pollute the atmosphere. } \\
\text { Use electricity, geothermal energy, gas } \\
\text { (including LPG), and other fuels as domestic } \\
\text { fuels to reduce the air pollution. }\end{array}$ & $\begin{array}{l}\text { As the winter had become severe, the use of improper } \\
\text { fuels such as rubber, plastic, and garbage, as well as coal, } \\
\text { also increased. Government officials pointed out the } \\
\text { low level of consciousness of residents in the ger areas. } \\
\text { Nevertheless, it appears that appropriate measures } \\
\text { were not taken. Currently, households use mainly } \\
\text { electricity and coal for cooking, and they still use coal } \\
\text { for a considerable proportion of their heating needs. }\end{array}$ & $\begin{array}{l}\text { The workshop participants sought information and } \\
\text { facilities for using gaseous fuels, especially LPG, for } \\
\text { cooking. Furthermore, they emphasized that if the } \\
\text { information on insulation materials for the gers is } \\
\text { available and the performance of the insulation } \\
\text { materials improves, then, the use of coal for heating at } \\
\text { home will be reduced. }\end{array}$ \\
\hline
\end{tabular}




\section{Discussion}

In this study, personal interviews with central and local government, agencies, NGOs, international organizations, and academia were conducted to describe the current situation regarding the risk management of Ulaanbaatar's air pollution problems. Through the workshop with the participation of the residents in the ger area, authentic opinions about their air pollution problems were heard and recorded. Based on the results, the gaps between the policy approaches of the government, the actual conditions, and the desired situations of the residents to improve air quality in Ulaanbaatar were analyzed.

Through the field visits during the winter of 2017, it was possible to observe firsthand that the whole city of Ulaanbaatar was covered with smog that was threatening the health of citizens. The main cause of this air pollution is attributed to the combustion of coal for heating in households in the ger areas. The results of this study demonstrate that the reduction of air pollution in Ulaanbaatar requires solutions for fundamental and complex problems that are based on a better understanding of the specific conditions and needs of the residents of the ger areas.

Ulaanbaatar's severe air pollution is a long-standing problem that has been worsening. The GoM considers the air pollution issue in Ulaanbaatar to be a top priority. The GoM is working with local and international agencies to reduce air pollution and improve air quality. However, there is a gap in the communication and understanding between the government officials and the residents of the ger areas. For example, the government officials consider that their policies are ineffective owing to the low level of consciousness of the citizens. This study showed that contrary to this perception, at least among the residents who participated in the workshop, the level of citizens' awareness of the air pollution problem is not low. The ger area residents were well aware of the severity of the air pollution problem and its causes.

According to the results of the interviews and the workshop observations and based on the analysis of air pollution related policies and the needs of the residents in the ger areas, several recommendations concerning air pollution in Ulaanbaatar are proposed.

The use of coal in the ger areas, the main air pollution source in Ulaanbaatar, is unlikely to reduce in the near future unless the ger area residents' poor living conditions and lack of infrastructure are addressed. In addition, though the introduction and utilization of clean or renewable energy is being promoted, its adoption by the community is slow. Thus, providing cleaner methods of using coal, and information and technology for low-cost insulation solutions for the ger area households, will help the residents in reducing their use of coal. Furthermore, a cost-benefit analysis supporting cleaner fuel options for the residents by considering their economic situation and provision of energy alternatives for household cooking and heating is required to help alleviate the problem.

The government's reduction of electricity charges and zero-cost policy for electricity from 9 p.m. to 6 a.m. is not realistic because the residents of the ger areas do not have electric stoves as they are unaffordable. Therefore, policymakers need to gather extensive opinions from the residents such that their policies better reflect the ger area residents' living conditions and needs.

Residents of Ulaanbaatar realize the seriousness of air pollution and that it is a threat to their lives. The government should pay more attention to the voices of the residents and implement measures that are more in line with the needs and capacities of the residents. Furthermore, knowledge and experience sharing sessions for the residents in the ger areas, for example, on insulation materials and clean energy options, would lead to actions that can be implemented by citizens to reduce air pollution. Thus, the country may be able to escape the vicious cycle of long-standing air pollution in Ulaanbaatar.

\section{Conclusions}

The objective of this study was to identify important challenges and barriers that have limited the success of various government policies that tackle air pollution problems in the ger areas of Ulaanbaatar, Mongolia. The study illustrated how participatory approaches were used in air pollution research to present the public discourse and convey community preferences, thereby arriving at policy directions that minimize the gaps between policy and practice. 
Through the resident workshop, this study demonstrated that community-based participatory approaches can be effective in the cultural context of Mongolia. Residents voluntarily participated without compensation or expectation of future compensation/benefits and showed creative ideas that could be considered in policymaking. These types of approaches can be applied in the ger areas in Mongolia to raise awareness and empower residents to act appropriately.

Author Contributions: Conceptualization, B.K. and A.M.C.; Methodology, B.K. and J.-I.N.;Validation, B.K., J.-I.N., and A.M.C.; Formal Analysis, B.K.; Investigation, B.K.; Resources, B.K.; Data Curation, B.K.; Writing-Original Draft Preparation, B.K.; Writing-Review and Editing, B.K., J.-I.N., T.T., and A.M.C.; Visualization, B.K. and T.T.; Supervision, J.-I.N., T.T., and A.M.C.; Project Administration, B.K. and A.M.C.; and Funding Acquisition, B.K. and A.M.C. All authors have read and agreed to the published version of the manuscript.

Funding: This work was supported by the Ministry of Education of the Republic of Korea and the National Research Foundation of Korea (NRF-2017S1A5B8059946). This research was funded by the National Research Foundation of Korea Grant funded by the Korean Government.

Conflicts of Interest: The authors declare no conflict of interest.

\section{References}

1. Fullerton, D.; Bruce, N.; Gordon, S. Indoor air pollution from biomass fuel smoke is a major health concern in the developing world. Trans. R. Soc. Trop. Med. Hyg. 2008, 102, 843-851. [CrossRef] [PubMed]

2. World Health Organization. WHO|WHO Global Urban Ambient Air Pollution Database. Retrieved from World Health Organization. 2016. Available online: https://www.who.int/phe/health_topics/outdoorair/databases/ cities/en/ (accessed on 17 March 2020).

3. Rafaj, P.; Kiesewetter, G. Outlook for clean air in the context of sustainable development goals. Glob. Environ. Chang. 2018, 53, 1-11. [CrossRef]

4. Mannucci, P.M.; Franchini, M. Health Effects of Ambient Air Pollution in Developing Countries. Int. J. Environ. Res. Public Health 2017, 14, 1048. [CrossRef] [PubMed]

5. Bruce, N.; Perez-Padilla, R.; Albalak, R. Indoor air pollution in developing countries: A major environmental and public health challenge. Bull. World Health Organ. 2000, 78, 1078-1079. [PubMed]

6. Ezzati, M.; Kammen, D.M. The Health Impacts of Exposure to Indoor Air Pollution from Solid Fuels in Developing Countries: Knowledge, Gaps, and Data Needs. Environ. Health Perspect. 2002, 110, 1057-1058. [CrossRef] [PubMed]

7. Goyal, R.; Khare, M. Indoor Air Pollution and Health Effects. In Air Pollution: Health and Environmental Impacts; Gurjar, B.R., Molina, L.T., Ojha, C.S., Eds.; CRC Press: New York, NY, USA, 2020; pp. 109-110.

8. Gheorghe, A.; Ankhbayar, B.; Nieuwenhuyzen, H.; Sa, R. Mongolia's Air Pollution Crisis: A Call to Action to Protect Children's Health; UNICEF Mongolia: Ulaanbaatar, Mongolia, 2018.

9. United Nations Development Programme. Air Pollution in Mongolia: Opportunities for Further Actions; AARC Consultancy: Dublin, Ireland, 2019.

10. Asian Development Bank. Mongolia: Coal to Cleaner Fuel Conversion for Heating in Ger District and Power Generation; Asian Development Bank: Mandaluyong, Philippines, 2014.

11. Hill, L.D.; Edwards, R.; Turner, J.R.; Argo, Y.D.; Olkhanud, P.B.; Odsuren, M.; Guttikunda, S.; Ochir, C.; Smith, K.R. Health assessment of future $\mathrm{PM}_{2.5}$ exposures from indoor, outdoor, and secondhand tobacco smoke concentrations under alternative policy pathways in Ulaanbaatar, Mongolia. PLoS ONE 2017, 12, e0186834. [CrossRef] [PubMed]

12. Tsevegjav, B. Assessment of Urban Air Pollution Abatement Policy Implementation Vis-à-vis the Role of Household Energy Use in Ger Areas of Mongolia; University of Twente: Enschede, The Netherlands, 2013.

13. Park, H.; Fan, P.; John, R.; Ouyang, Z.; Chen, J. Spatiotemporal changes of informal settlements: Ger districts in Ulaanbaatar, Mongolia. Landsc. Urban Plan. 2019, 191, 103630. [CrossRef]

14. Bauner, S.; Richter, B. Real Estate Market, Mortgage Market and Cadastre in Ulaanbaatar and Darkhan-City, Mongolia; Gebhard: Heusenstamm, Germany; Deutsche Gesellschaft fürTechnische Zusammenarbeit (GTZ) GmbH: Bonn, Germany, 2006.

15. Miller, R. Settling between legitimacy and the law, at the edge of Ulaanbaatar's legal landscape. Tradit. Dwell. Settl. Rev. 2017, 29, 7-20. 
16. Wu, Y.; Nuorkivi, A.E.; Salminen, P.K.; Johansen, P.; Cui, R. Paving the Way to a Sustainable Heating Sector: A Roadmap for Ulaanbaatar Urban Heating (English); World Bank Group: Washington, DC, USA, 2019. Available online: http://documents.worldbank.org/curated/en/361331554753311754/Paving-the-Way-to-a-SustainableHeating-Sector-A-Roadmap-for-Ulaanbaatar-Urban-Heating (accessed on 31 March 2020).

17. Frankfurt School of Finance and Management, United Nations Environment Programme (UNEP). Financing Household Clean Energy Solutions; Climate and Clean Air Coalition (CCAC): Paris, France, 2018.

18. Baasanjav, B.-E. Research on Air Pollution in Mongolia Ulaanbaatar City: Focusing on the 'Ger' Areas; Gangwon University: Gangwon Province, Korea, 2015.

19. Long, P. Mongolia's Capital Copes with Rapid Urbanization|The Asia Foundation. Retrieved from The Asia Foundation. 31 May 2017. Available online: https://asiafoundation.org/2017/05/31/mongolias-capital-copesrapid-urbanization/ (accessed on 19 March 2020).

20. Guttikunda, S.; Lodoysamba, S.; Bulgansaikhan, B.; Dashdondog, B. Particulate pollution in Ulaanbaatar, Mongolia. Air Qual. Atmos. Health 2013, 6, 589-601. [CrossRef]

21. Amarsaikhan, D.; Battsengel, V.; Nergui, B.; Ganzorig, M.; Bolor, G. A Study on Air Pollution in Ulaanbaatar City, Mongolia. J. Geosci. Environ. Prot. 2014, 2, 123-128. [CrossRef]

22. Takemoto, Y.; Takahashi, M.; Awaya, K.; Ito, K.; Takeuchi, S. Numerical Simulation of Air Pollution in Ulaanbaatar City, Mongolia. J. Mater. Sci. Eng. 2015, 18, 187-195.

23. Sonomdagva, C.; Byambatseren, C.; Batdelger, B. Assessment of air pollution of settlement areas in Ulaanbaatar city, Mongolia. In Proceedings of the 7th International Conference on Environment and Industrial Innovation, Kuala Lumpur, Malaysia, 28-30 April 2017; IOP Publishing: Bristol, UK, 2017.

24. World Bank. Air Quality Analysis of Ulaanbaatar: Improving Air Quality to Reduce Health Impacts (Mongolian); World Bank: Washington, DC, USA, 2011.

25. Allen, R.; Gombojav, E.; Barkhasragchaa, B.; Byambaa, T.; Lkhasuren, O.; Amram, O.; Janes, C. An assessment of air pollution and its attributable mortality in Ulaanbaatar, Mongolia. Air Qual. Atmos. Health 2013, 6, 137-150. [CrossRef] [PubMed]

26. Jadambaa, A.; Spickett, J.; Badrakh, B.; Norman, R. The impact of the environment on health in Mongolia: A systematic review. Asia-Pac. J. Public Health 2014, 27, 45-75. [CrossRef] [PubMed]

27. United Nations Children's Fund (UNICEF). Understanding and Addressing the Impact of Air Pollution on Children's Health in Mongolia; UNICEF Mongolia: Ulaanbaatar, Mongolia, 2016.

28. Healey, P. Institutionalist analysis, communicative planning, and shaping places. J. Plan. Educ. Res. 1999, 19, 111-121. [CrossRef]

29. Faucheux, S. The Multi-Stakeholder Paradigm, ESEE Newsletter, No. 2; European Society for Ecological Economics: Paris, France, 1997; pp. 1-2.

30. Geurts Jac, L.A.; Joldersma, C. Methodology for participatory policy analysis. Eur. J. Oper. Res. Elsevier 2001, 128, 300-310. [CrossRef]

31. Okada, N.; Na, J.-I.; Fang, L.; Teratani, A. The Yonmenkaigi System Method: An Implementation-Oriented Group Decision Support Approach. Group Decis. Negot. 2012, 22, 53-67. [CrossRef]

32. Culbertson, A. Mongolians Drink Oxygen Cocktails to Cope with Smog in World's Most Polluted Capital; Sky News: London, UK, 2018. Available online: https://news.sky.com/story/mongolians-drink-oxygen-cocktails-tocope-with-smog-in-worlds-most-polluted-capital-11354476 (accessed on 2 April 2020).

33. Labmate Online. What Is an Oxygen Cocktail? Pollution Solutions. 16 May 2018. Available online: https:/www.pollutionsolutions-online.com/news/air-clean-up/16/breaking-news/what-isan-oxygen-cocktail/46054 (accessed on 2 April 2020).

34. Thompson, A. Mongolians Drink 'Oxygen Cocktails' and 'Lung Tea' to Cope with Air Pollution That Is More than 130 Times above Safe Levels. Daily Mail Online. 3 May 2018. Available online: https://www.dailymail.co.uk/health/article-5676859/Mongolians-sip-oxygen-cocktails-cope-smog.html (accessed on 2 April 2020).

35. Parliament of Mongolia. Law on Air Pollution Reduction in the Capital City; Parliament of Mongolia: Ulaanbaatar, Mongolia, 2011.

(C) 2020 by the authors. Licensee MDPI, Basel, Switzerland. This article is an open access article distributed under the terms and conditions of the Creative Commons Attribution (CC BY) license (http://creativecommons.org/licenses/by/4.0/). 